mianserin (Fig. 1c), a potent antagonist at insect octopamine receptors in vitro $^{4,5}$ and active in honeybees in vivo ${ }^{7}$.

The effective doses in this study were at least three orders of magnitude larger than endogenous levels in the brain ${ }^{8}$. Direct application to the brain might have allowed the use of lower doses, but would probably not have been compatible with a bioassay with unrestrained bees. Another possible side effect of this bioassay was that control bees did not discriminate between nestmates and non-nestmates as well as they normally $\mathrm{do}^{2}$, perhaps because of the smaller group size.

Nestmate recognition is thought to require an individual to form a mental template based on learned (presumably olfactory) recognition cues of itself or its close relatives; the similarity of a conspecific's recognition cues to those represented by the template is then used to assess relatedness. We suggest that a higher octopamine concentration improves nestmate recognition by acting as a neuromodulator in the brain and increasing attention to relevant olfactory stimuli, so that fewer recognition mistakes are made. This is consistent with the finding that differences between treated and control bees resulted in both decreased aggression towards nestmates and increased aggression towards non-nestmates. It is also consistent with previous findings for bees that octopamine increases the rate of antennal scanning ${ }^{9}$, improves performance on an olfactory learning test ${ }^{4}$, and decreases the threshold of response for behavioural stimuli in other systems ${ }^{10}$. Octopamine levels in the bee brain increase with age ${ }^{8}$, and older bees are more defensive than younger bees. These results demonstrate that kin recognition, with widespread occurrence and compelling adaptive significance, offers promising experimental material for neuroethological analysis.

Gene E. Robinson ${ }^{\star} \uparrow$, Laura M. Heuser ${ }^{\star}$, Yves LeConte $\ddagger$, Frederic Lenquette $\ddagger \varsigma$, Robert M. Hollingworth

${ }^{*}$ Department of Entomology, University of Illinois, Urbana, Illinois 61801, USA

e-mail: generobi@uiuc.edu

$\dagger$ Neuroscience Program, University of Illinois,

Urbana, Illinois 61801, USA

\$INRA, Unite de Zoologie,

Laboratoire de Biologie de L'Abeille,

F-84914 Avignon Cedex 9, France

$\$ C N R S$, Laboratoire de Neurobiologie-

Communication Chimique,

F-13402 Marseille Cedex 9, France

IPesticide Research Center and Department of

Entomology, Michigan State University,

East Lansing, Michigan 48824, USA

1. Hamilton, W. D. J. Theor. Biol. 7, 1-32 (1964).

2. Breed, M. D. Anim. Behav. 31, 86-91 (1983).

3. Mercer, A. R. \& Erber, J. J. Comp. Physiol. A 151, 469-476 (1983).

4. Orr, N., Orr, G. L. \& Hollingworth, R. M. Insect Biochem. 21, 335-340 (1991).
5. Orr, N., Orr, G. L. \& Hollingworth, R. M. Insect Biochem. Mol. Biol. 22, 591-597 (1992).

6. Lund, A. E., Hollingworth, R. M. \& Shankland, D. L. Pestic Biochem. Physiol. 11, 117-128 (1979).

7. Burrill, B. \& Smith, B. H. J. Insect Physiol. 41, 671-680 (1995)

8. Wagener-Hulme, C., Kuehn, J. C., Schulz, D. J. \& Robinson, G. E. J. Comp. Physiol. A (in the press)

9. Pribbenow, B. \& Erber, J. Neurobiol. Learn. Mem. 66, 109-120 (1996).

10. Linn, C. E. \& Roelofs, W. L. Arch. Insect Biochem. Physiol. 3 , 161-171 (1986).

\section{Parameters for global ecosystem models}

Tian et al. ${ }^{1}$ have used their process-based ecosystem model to estimate the net $\mathrm{CO}_{2}$ exchanges, also called net ecosystem productivity, for the years 1980-94. They deduced a large interannual variability ranging between -0.2 (from land to atmosphere) and +0.7 petagrams of carbon (Pg C) per year, the variability being mostly a function of soil moisture, which in turn is largely regulated by precipitation and temperature. These values were derived by including the modelled effects of increasing atmospheric levels of $\mathrm{CO}_{2}$. The above numbers are the differences between net primary productivity and heterotrophic respiration. Over the given time period for the $\mathrm{CO}_{2}$ feedback case, these values were 5.0 $( \pm 0.3)$ and $4.8( \pm 0.1)$ Pg C per year, respectively. The calculated net ecosystem productivity was thus a small fraction, between $-4 \%$ and $+14 \%$, of the net primary productivity, with an average over the 15 -year period of $+4 \%$.

We wish to point out that another carbon-release process, involving the emissions of isoprene $\left(\mathrm{C}_{5} \mathrm{H}_{8}\right)$ and other volatile organic compounds (VOCs) from the Amazon vegetation to the atmosphere, must be taken into account. Guenther et al. ${ }^{2}$ have estimated a global VOC emission of $1.15 \mathrm{Pg} C$ per year, corresponding to an average global fraction of $2.4 \%$ of the net primary productivity. With the relatively larger VOC contributions from deciduous forests, this fraction will be of the order of 3\% for tropical forests. The oxidation of isoprene to $\mathrm{CO}_{2}$ does not occur promptly, but involves many reactions in which compounds such as $\mathrm{CO}$ and oxidized hydrocarbons are formed; these compounds have lifetimes of the order of days to a month (in the case of $\mathrm{CO})$. The neglect of VOC emissions can lead to a substantial underestimate of the ultimate release of carbon from the tropical ecosystems to the atmosphere.

In our research in the forested regions of Surinam during March 1998 (refs 3,4), we used a proton-transfer-reaction mass spectrometer on an aircraft to detect VOCs. We measured not only high concentrations of short-lived (hours) isoprene averaging 2.8 $\mathrm{nmol} \mathrm{mol}{ }^{-1}$, but also high concentrations of up to $13.5 \mathrm{nmol} \mathrm{mol}^{-1}$ of various VOC compounds with a positive ion mass of 43 atomic mass units such as propan-2-ol, as well as formic acid and acetic acid with average

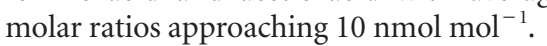

In agreement with Guenther et $a l^{2}$, we conclude that a proper forest-ecosystem carbon budget analysis must take into account the emissions of VOCs as well as of $\mathrm{CO}_{2}$. Not only are direct emissions of VOCs from intact vegetation important, but leaf wounding is a significant additional source of $\mathrm{VOCs}^{5}$; herbivores consume (and thus wound) about $40 \%$ of tropical forest aboveground net foliar production ${ }^{6}$. Research is greatly needed to make better estimates of these emissions and the processes affecting them in order to expand the model of Tian et al. ${ }^{1}$. This is also important for an understanding of the air chemistry above the tropical forests and its influence on global chemistry $^{7,8}$.

The occurrence of fires is an additional factor that must be taken into account. 'Dry' years, during which emissions of $\mathrm{CO}_{2}$ are highest owing to low soil humidity ${ }^{1}$, are also years of more extensive fires in the tropics, further increasing the interannual variability of carbon release.

Paul J. Crutzen`, Ray Fall $\dagger$, Ian Galbally $\neq$, Werner Lindinger $\$$

${ }^{*}$ Max-Planck-Institute for Chemistry, PO Box 3060, 55020 Mainz, Germany

e-mail:air@mpch-mainz.mpg.de

$\dagger$ Department of Chemistry and Biochemistry, University of Colorado, Boulder,

Colorado 80309, USA

$\ddagger$ Division of Atmospheric Research, CSIRO,

Private Bag 1, Aspendale, Victoria 3195, Australia $\$$ Institute for Ion Physics, University of Innsbruck, A-6020 Innsbruck, Austria

\footnotetext{
1. Tian, H. et al. Nature 396, 664-667 (1998).

2. Guenther, A. et al. J. Geophys. Res. 100, 8873-8892 (1995).

3. Warneke, C. et al. J. Atmos. Chem. (submitted).

4. Williams, J. et al. J. Atmos. Chem. (submitted).

5. Kirstine, W. et al. J. Geophys. Res. 103, 10605-10619 (1998).

6. Randerson, J. T. et al. Global Biogeochem. Cycles 10, 585-602 (1996)

7. Houweling, S., Dentener, F. \& Lelieveld, J. J. Geophys. Res. 103, 10673-10696 (1998)

8. Wang, Y., Jacob, D. J. \& Logan, J. A. J. Geophys. Res. 103, 10757-10767 (1998)
}

We agree that the Terrestrial Ecosystem Model analyses by Tian et al. ${ }^{1}$ of carbon fluxes of Amazonian ecosystems represent a methodological improvement compared with extrapolation from site-specific estimates ${ }^{2}$, especially with regard to spatial resolution. However, the resolution of a model cannot be finer than that of the input data, and Tian et al. disregard one important group of ecosystems: peatlands. This is understandable, as the literature grossly underestimates the extent of peatlands in Amazonia. Our estimate is $150,000 \mathrm{~km}^{2}$, ten times more than previously reported.

A global peat resource assessment ${ }^{3}$ erroneously implied a mire area of $15,000 \mathrm{~km}^{2}$ 
for the Amazon Basin, limited to Brazil. But western Amazonia harbours extensive swamps dominated by the palm Mauritia flexuosa L.f., as well as innumerable smaller mires along rivers, around lakes, in stream valleys, and in minor depressions within the rainforest. Mauritia swamps are estimated to cover $47,140 \mathrm{~km}^{2}$ in $\mathrm{Peru}^{4}$, and vegetation maps suggest $8,000 \mathrm{~km}^{2}$ for Colombia $^{5}$ and $4,000 \mathrm{~km}^{2}$ for Ecuador ${ }^{6}$. Our work indicates that peat strata in these swamps are often more than a metre thick. Considerable areas of such peatlands are also thought to exist in Brazil ${ }^{7}$.

Small mires within the rainforest are difficult to map, because they are indistinguishable in satellite images. However, on the basis of experience from $220 \mathrm{~km}$ of floristic transects in Peruvian, Colombian and Ecuadorian non-inundated rainforests, we estimate that peat deposits cover about $1 \%$ of their area, totalling almost $9,000 \mathrm{~km}^{2}$. If the same proportion applies in Brazil, then it has more than $40,000 \mathrm{~km}^{2}$ of undocumented peatlands intermingled with 'true' rainforest. In addition, Bolivia, Venezuela and the Guyanas are likely to harbour unreported mires. Hence, we estimate that there are around $150,000 \mathrm{~km}^{2}$ of peatlands throughout Amazonia.

The average net ecosystem production of peatland ecosystems has remained positive for millennia, manifested by accumulation of peat. In nutrient-poor boreal mires, summertime (5 months) net ecosystem production can be $119 \mathrm{~g} \mathrm{C} \mathrm{m}^{-2}$ (ref. 8), about three times the average (1980-94) annual value (about $42 \mathrm{~g} \mathrm{C} \mathrm{m}^{-2}$, "climate with $\mathrm{CO}_{2}$ ") reported by Tian et al. ${ }^{1}$ for the Amazon Basin. However, peat deposits can also release considerable amounts of carbon. When the water-table is exceptionally low, summertime carbon emissions from boreal peatlands can be $83 \mathrm{~g} \mathrm{~m}^{-2}$ (ref. 8), more than twice the highest annual value (about $40 \mathrm{~g} \mathrm{~m}^{-2}$ ) of Amazonia ${ }^{1}$. Hardly any data exist on carbon fluxes of tropical peatlands. During drought, constantly high temperatures presumably render them strong carbon emitters. As soil moisture is apparently an important controller of carbon storage in Amazonia ${ }^{1}$, incorporating such a response into the Terrestrial Ecosystem Model would further increase carbon emissions in El Niño years. The net ecosystem production of Amazonian peatlands is hard to estimate without ecological knowledge of the systems, but it might significantly affect the total carbon budget of the basin.

Finally, the soil organic carbon density $\left(C_{\mathrm{s}}\right)$ estimate $^{9}$ used to validate the Terrestrial Ecosystem Model $^{1}$ was based on the RADAMBRASIL survey ${ }^{10}$, which excluded peat soils and covered only Brazil. When peatlands and other Amazonian countries are also included, $C_{\mathrm{s}}$ becomes close to $12 \mathrm{~kg} \mathrm{C} \mathrm{m}{ }^{-2}$, which is $30 \%$ greater than the value obtained with the Terrestrial Ecosystem Model ${ }^{1}$.

\section{Leif Schulman, Kalle Ruokolainen,}

\section{Hanna Tuomisto}

Department of Biology, Section of Ecology, University of Turku, FIN-20014 Turku, Finland e-mail:leif.schulman@utu.fi

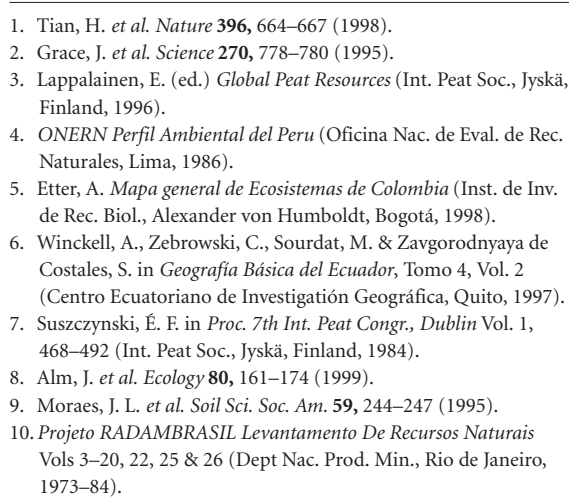

3. Lappalainen, E. (ed.) Global Peat Resources (Int. Peat Soc., Jyskä, Finland, 1996).

4. ONERN Perfil Ambiental del Peru (Oficina Nac. de Eval. de Rec. Naturales, Lima, 1986).

5. Etter, A. Mapa general de Ecosistemas de Colombia (Inst. de Inv. de Rec. Biol., Alexander von Humboldt, Bogotá, 1998).

6. Winckell, A., Zebrowski, C., Sourdat, M. \& Zavgorodnyaya de Costales, S. in Geografía Básica del Ecuador, Tomo 4, Vol. 2 (Centro Ecuatoriano de Investigatión Geográfica, Quito, 1997).

7. Suszczynski, É. F. in Proc. 7th Int. Peat Congr., Dublin Vol. 1, 468-492 (Int. Peat Soc., Jyskä, Finland, 1984).

8. Alm, J. et al. Ecology 80, 161-174 (1999).

9. Moraes, J. L. et al. Soil Sci. Soc. Am. 59, 244-247 (1995).

10. Projeto RADAMBRASIL Levantamento De Recursos Naturais Vols 3-20, 22, 25 \& 26 (Dept Nac. Prod. Min., Rio de Janeiro, 1973-84).

Tian et al. reply - Our model-based analysis of the effects of interannual climate variability and increasing atmospheric $\mathrm{CO}_{2}$ concentration on carbon storage in Amazonian ecosystems focused on $\mathrm{CO}_{2}$ exchanges between the atmosphere and undisturbed forests and other upland ecosystems of the region ${ }^{1}$. Crutzen et al. urge us to add the emissions of isoprene and other volatile organic compounds (VOCs) to our analysis. They argue that ignoring these emissions could lead to an overestimation of annual net carbon storage (net ecosystem production) in the Amazon Basin.

We did not include VOCs in our Terrestrial Ecosystem Model because not enough is known about their production, such as controls on rates, and tree species involved ${ }^{2}$. The parameterization of $\mathrm{CO}_{2}$ uptake (gross primary production) in the model is based on an estimate of the sum of net primary production and plant respiration, and does not include allocation of carbon to support the production of VOCs. Because we make no allowances in the model for $\mathrm{CO}_{2}$ uptake by plants to support the production of VOCs, we make no allowances for emissions associated with VOCs. The estimates of net ecosystem production in our current version of the model are therefore independent of VOC emissions, and should not be corrected downwards for them.

However, the future development of the Terrestrial Ecosystem Model will certainly include the addition of VOCs because of their importance in tropospheric chemistry. Because the model is subject to mass balance constraints, we expect that our estimates of both gross primary production and net primary production will increase to accommodate the addition of VOC fluxes.

Schulman et al. suggest that we consider carbon fluxes between the atmosphere and peatlands in our calculations of net ecosystem production for the Amazon Basin.
They state that these ecosystems cover a large area, and they assume that tropical peatlands are likely to be at least as responsive to climate changes as their boreal counterparts. From our review of the literature on the areal extent of peatlands in Amazonia ${ }^{3,4}$, we conclude that Schulman et al.'s estimate of peatland area in the basin, $150,000 \mathrm{~km}^{2}$, is reasonable. If we combine the total peatland area of Amazonia with the boreal peatland flux rates cited by Schulman et al., the resulting basin-wide fluxes are small. A carbon storage rate (positive net ecosystem production) of $119 \mathrm{~g} \mathrm{C} \mathrm{m}^{-2} \mathrm{yr}^{-1}$ translates to an annual basin-wide storage of about $0.02 \mathrm{Pg} \mathrm{C}$, and a carbon loss rate (negative net ecosystem production) of $83 \mathrm{~g} \mathrm{C} \mathrm{m}^{-2} \mathrm{yr}^{-1}$ translates to an annual basin-wide release of about $0.01 \mathrm{Pg}$ C. For interannual climate variability to have a significant effect on the net ecosystem production of Amazonia through peatlands, these ecosystems would have to be much more sensitive than boreal peatlands to climate shifts.

There is evidence that this is not the case. The literature on peatlands in warm climates indicates that, because of the poor quality of their organic matter, decomposition rates in these ecosystems are low under both aerobic and anaerobic conditions ${ }^{5}$. This is not true for boreal peatlands, where the low temperatures that prevail for most of the year slow the decay of plant litter. Slow decay leads to a build-up of relatively high-quality organic matter that decomposes rapidly under warmer and drier conditions. Because tropical peatlands may be less sensitive than boreal peatlands to interannual climate variability, and because the area of peatlands is relatively small in Amazonia, we conclude that the net ecosystem production of the Amazon Basin is little influenced by the effects of year-to-year variability on carbon storage in its peatlands.

Hanqin Tian*, Jerry M. Melillo*,

David W. Kicklighter ${ }^{\star}$, A. David McGuire†, Berrien Moore III

* The Ecosystems Center,

Marine Biological Laboratory,

Woods Hole, Massachusetts 02543, USA

$\dagger$ US Geological Survey,

Cooperative Fish and Wildlife Research Unit,

University of Alaska, Fairbanks, Alaska 99775, USA ‡Institute for the Study of Earth, Oceans and Space, University of New Hampshire,

New Hampshire 03824, USA

1. Tian, H. et al. Nature 396, 664-667 (1998).

2. Lerdau, M., Guenther, A. \& Monson, R. Bioscience 47, 373-383 (1997).

3. Junk, W. J. in Mires: Swamp, Bog, Fen and Moor (ed. Gore, A. J. P.) 269-294 (Elsevier, Amsterdam, 1983).

4. Junk, W. J. in Transport of Carbon and Minerals in Major World Rivers (eds Degens, E. T. H., Kempe, S. \& Herrera, R.) 267-283 (Mitt. Geol-Palaont. Inst. Univ. Hamburg, SCOPE/UNEP Sonderbd, Hamburg, 1985).

5. Bridgham, S. D. \& Richardson, C. J. Soil Biol. Biochem. 24 1089-1099 (1992). 